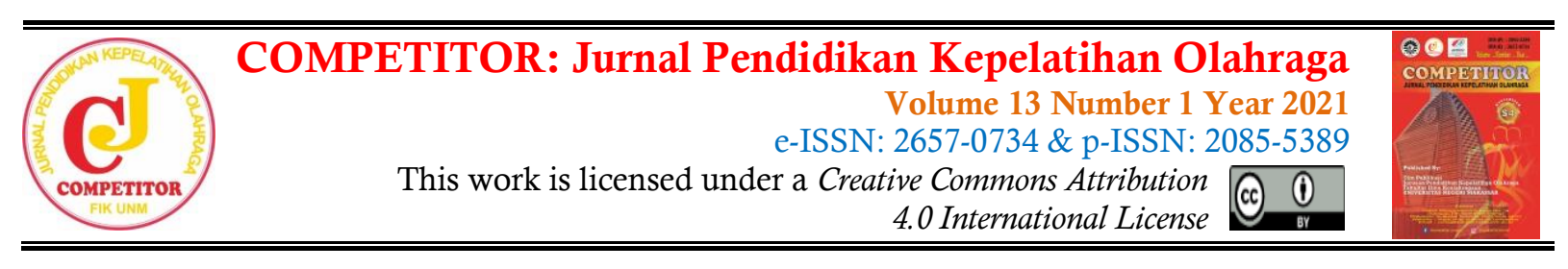

\title{
Influence of Small Side Games (SSG) on Aerobic Endurance and Handball Skills
}

\author{
Fitra Agung Aditya Pratama ${ }^{1^{*}}$, Yunyun Yudiana ${ }^{2}$, Tite Juliantine ${ }^{3}$ \\ ${ }^{1,2,3}$ Postgraduate Program/Indonesian Education University/West Java/Indonesia \\ 1,2,3 J1. Dr. Setiabudhi No.229, Isola, Kec. Sukasari, Bandung City, West Java, 40154 \\ 1itra.agung@upi.edu, 22yunyunyudiana@upi.edu, 3juliantinetite@gmail.com
}

Received: December 03, 2021; Reviewed: 13 January, 2021; Accepted: 19 January, 2021; Published: February 28, 2021

\begin{abstract}
The purpose of this study was to determine the effect and difference between small side games (SSG) and small side games with tournament (SSGT) on aerobic endurance (endurance) and skills in playing football. The method used in this research is a quasi experimental design with the random pretest-posttest control group design research design. The instrument used is HTPE (The Handball Tactical Performance) to measure playing skills while the Bronco test is to measure endurance. The results showed that there was no significant increase in the SSG training program on the increase in VO2max, while for the playing performance variable the SSG exercise program showed a significant increase. In the SSGT program there is a significant increase in the increase in VO2max and playing performance in PORDA athletes in Kab. West Bandung. Based on the results of the independent sample t-test, there is no significant difference between the SSG training program and the SSGT training program on playing performance, but there is a significant difference between the SSG training program and the SSGT training program on the increase in VO2max in PORDA athletes in Kab. West Bandung.
\end{abstract}

Keywords: Small Side Games (SSG); Aerobic Endurance; Playing Skills; Handball.

\section{INTRODUCTION}

Handball or often known as Handball defined by the International Handball Federation is a fast game involving two teams and seven players who are adept at throwing, catching and dribbling a small ball with a hand that aims to try to score a goal (Milanese, Piscitelli, Lampis, \& Zancanaro, nd). As well as Taylor et al., (2010) stated that handball is a team sport with high-intensity physical contact including running, jumping, hitting, blocking and pushing. Handball is classified as a high-intensity sport. The intensity and volume of handball play activities in a dynamic match is heterogeneous because two opposing teams take turns taking either attacking or defending roles and the field players are in physical contact on the playing field to win each other's matches (Corvino, Vuleta, \& Šibila, 2016). Like other team sports, shooting the ball at goal is the 
Influence of Small Side Games (SSG) on Aerobic Endurance and Handball Skills

Fitra Agung Aditya Pratama ${ }^{*}$, Yunyun Yudiana ${ }^{2}$, Tite Juliantine ${ }^{2}$

fitra.agung@upi.edu

pinnacle or goal of the offensive or attack phase, and success and failure depend on whether the team scores or not (Manchado, García-Ruiz, Cortell-Tormo, \& TortosaMartínez, 2017). Therefore, every handball athlete must have good tactical skills or skills, as well as excellent physical condition.

Physical condition is one of the important elements or factors to achieve an achievement in sports. As Giriwijoyo (2007) states that good physical condition must be possessed by an athlete because it is a condition that cannot be ignored and is very important in achieving high achievement. In line with this, Martens (2004) states that physical condition is the ability to face the physical demands of a sport to perform optimally. According to the opinion (Candra et al., 2019) that the physical condition exercises given must be able to develop the ability of general and specific physical conditions according to the sporting needs required for matches / competitions, the formation of the physical conditions required in the competition takes a long time and must be done with a directed and systematic training plan. Therefore, efforts to improve physical conditions must be developed according to the needs of the sport. Speed, agility, leg length, grip strength, abdominal muscular, endurance, leg explosive, wrist flexibility, shoulder flexibility and hip flexibility are the support or support for the success of handball athletes. Endurance is the ability to work, train for a long time. General endurance. Specific endurance is known as muscle endurance or anaerobic endurance "(Tanzila, Chairani, \& Prawesti, 2018). Meanwhile, according to Harsono (2016, p. 11) endurance aerobics is a condition or condition of the body that is able to work or train for a long time, without experiencing excessive fatigue after completing work or training. In addition to being required to have a prime physique, athletes are also required to be technically and tactical meaning that physical, technical and tactical conditions are inseparable part What is meant by endurance in this case is circulatory-respiratory endurance or there is something called cardiovascular endurance.

Technique is a skill that must be possessed by every athlete in the sport he is engaged in. The game will run well if each player is able to master the techniques of the game. Basic techniques are all basic activities, so that with good basic technical capital, athletes will be able to play well in all positions. Basic techniques are basic skills that must be mastered in order to achieve high achievement. Included in handball, athletes must be able to do dribbling, passing, cathching, shooting and others. As Sridadi, and Utama, revealed that handball games will run well if they are able to master handball skills. Therefore, to hone and improve the basic skills of playing handball such as 
Influence of Small Side Games (SSG) on Aerobic Endurance and Handball Skills

Fitra Agung Aditya Pratama ${ }^{*}$, Yunyun Yudiana ${ }^{2}$, Tite Juliantine ${ }^{2}$

fitra.agung@upi.edu

throwing, jumping and running, there must be a practice strategy effort or a learning model that is easy to understand and efficient for every handball player. In the process of training or learning handball, efforts are made to practice or learn in accordance with the actual conditions when competing (Aguiar, Botelho, Lago, Maças, \& Sampaio, 2012). One of the problems related to knowledge of the methods and forms of training in implementing training methods.

A well planned exercise program taking into account appropriate physiological stimuli is an effective way to disrupt homeostasis and force the body to adapt to exercise (Costa, Balasekaran, Vilas-Boas, \& Barbosa, 2015). During the training program there is an increase in training capacity and performance. Likewise, aerobic exercise makes the heart and lungs more efficient, and with the addition of high-intensity anaerobic training will increase muscle strength and speed through neuromuscular, metabolic, and cardiovascular adaptations (Kenney, Wilmore, \& Costill, 2012). Anaerobic and aerobic endurance are important components in sports (Akbar, 2013). Endurance depends on the presence of oxygen, muscles need oxygen intake so that they are not easy to experience fatigue when doing sports activities (Citizen, 2015). Because, oxygen has a role that supports the respiration of muscle cells while doing sports activities to produce energy. In every sport, there must be a strategy or method to get maximum results. The use of appropriate training methods can maximize the talents and achievements of athletes until the peak performance of a particular skill or activity requires repetition of activities aimed at mastering these skills. According to Harsono (2016, p. 38) Maximum exercise will optimize one's talents and abilities so as to achieve satisfactory results. Differences in athletes are unique in humans, so that in determining the training method and making the training program itself requires more detailed handling so that athlete's achievement can be maximized. One of the training methods that can be used to achieve the goal of an achievement, especially in the invasion of team games, is the attack and defense process, namely the small sided games training method.

Small-side games present organizational characteristics similar to formal games or real games (Davids, Arau, \& Correia, 2013). Teaching or training models that focus on declarative / procedural tactical knowledge use small sided games to facilitate players' understanding of formal or actual play (Aguiar, Botelho, Lago, Maças, \& Sampaio, 2012). Modifying SSG conditions can change environmental characteristics in a controllable method and can encourage athletes / students to perform the desired behavior (Davids et al., 2013). The use of the SSG method is also very effective in 
Influence of Small Side Games (SSG) on Aerobic Endurance and Handball Skills

Fitra Agung Aditya Pratama ${ }^{1^{*}}$, Yunyun Yudiana ${ }^{2}$, Tite Juliantine ${ }^{2}$

fitra.agung@upi.edu

developing the capacity for strength, speed and aerobic speed endurance (Radziminski, Rompa, Barnat, Dargiewicz, \& Jastrzebski, 2013). Therefore, systematic changes in SSG conditions allow teachers and trainers to adapt tactical demands, techniques and physical conditions according to their practice or training objectives.

Actually, the success of the first small sided games training method was applied to the soccer branch. After many studies that have applied small sided games in other sports, including handball. One of the efforts to improve the handball training method is a method that stimulates athletes to become accustomed to playing situations. Thus, the author wants to review the tests related to previous studies on the effect of the small side games method on improving the physical condition and skills of playing handball in athletes.

\section{METHOD}

The method used in this research is a quasi experimental design method. In experimental research, there are various kinds of research designs. The design used in this study was the random pretest-posttest control group design.

\begin{tabular}{cllll}
\hline Treatment Group & $\mathrm{R}$ & $\mathrm{O}_{1}$ & $\mathrm{X}$ & $\mathrm{O}_{2}$ \\
Control Group & $\mathrm{R}$ & $\mathrm{O}_{1}$ & $\mathrm{C}$ & $\mathrm{O}_{2}$ \\
\hline
\end{tabular}

Ficture 1.

Research design

The location of this research was carried out at the Inspire arena and the Pajajaran Sports Hall which is located at Jalan Parompong and Jalan Pajajaran, Bandung City, West Java. The population in this study were male athletes in West Java who were actively involved in training activities consisting of 27 cities and districts in West Java as the research object. Researchers only took one city or district as the research sample using cluster random sampling technique. Fraenkel \& Wallen, (2012) stated that cluster random sampling is the selection of random group samples. As for the samples in this study were male athletes of West Bandung Regency. The details are as follows ;

Table 1.

Research Samples

\begin{tabular}{ccc}
\hline Category & Year & Amount \\
\hline PORDA & 1998 & 16 \\
POPDA & 2003 & 16 \\
\hline
\end{tabular}


The instrument used in the researcher took 2 tests related to the variables studied, namely a test to measure handball playing skills using HTPE (The Handball Tactical Performance) and a test to measure endurance using the Bronco test ( $1.2 \mathrm{~km}$ suttle run) . Data processing techniques in this study using computational computation program SPSS (Statistical Product and Service Solution) version 22.0 for windows. The processing steps are: normality test, homogeneity test, Paired Sample t-test \& Independent sample t-test.

\section{RESULTS AND DISCUSSION}

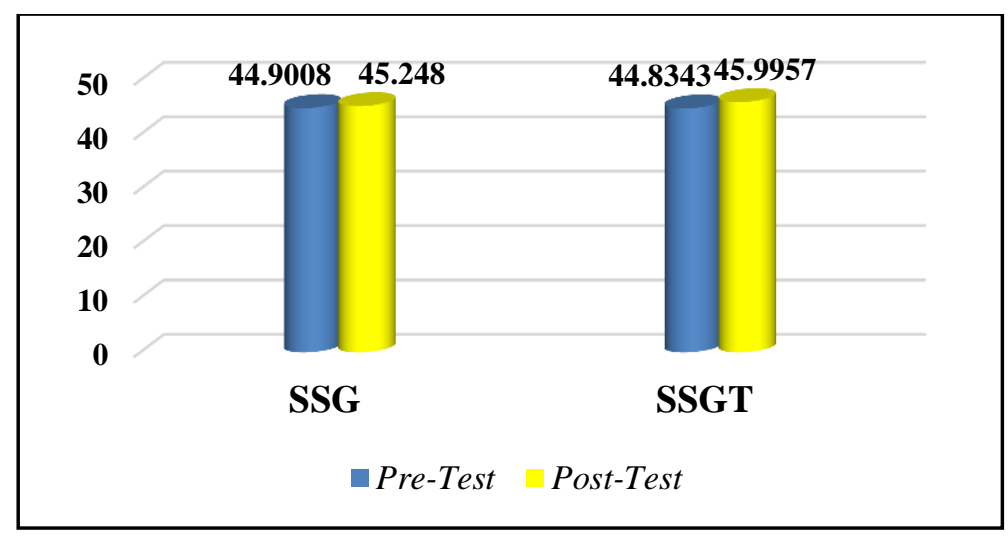

Ficture 2.

Play Performance Mean Score Diagram

Based on the bar chart image above, it can be concluded that the average score of playing performance in the SSGT group has increased significantly compared to the SSG group. As at the time of the SSGT group pretest the average value was obtained ( $\pi=$ $32.8469)$ and at the posttest the average value was obtained $(\pi=35.7500)$ which means an increase of 2.9031. Whereas in the SSG group at the pretest, the average value was obtained ( $\pi=34.1344)$ and at the posttest the average value was obtained $(\pi=36.5656)$ which means that it increased by 2.4312 .

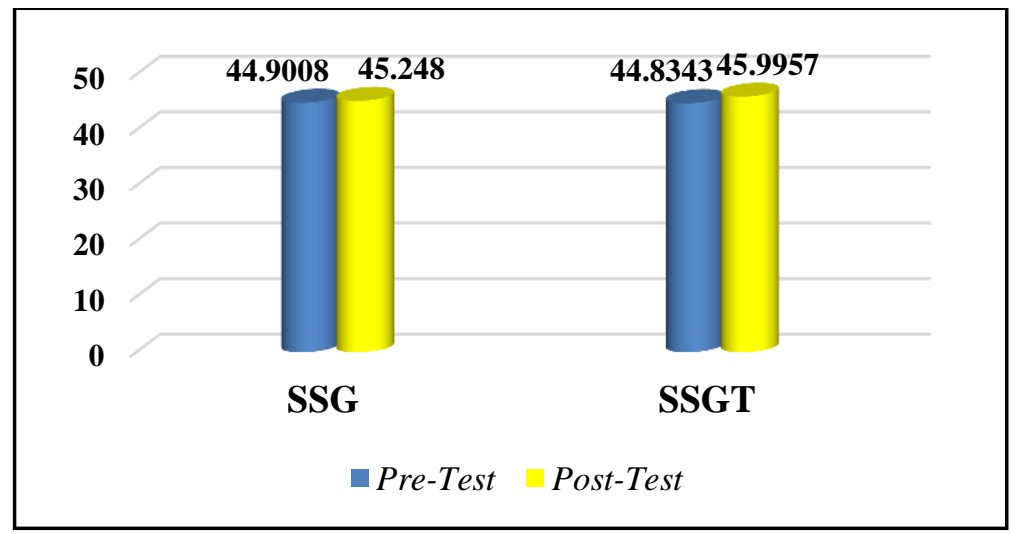

Ficture 3.

VO2max Mean Score Diagram 
Based on the bar chart image above, it can be concluded that the mean VO2max value in the SSGT group experienced a more significant increase compared to the SSG group. As at the time of the SSGT group pretest the average value was obtained ( $\pi=$ $44.8343)$ and at the posttest the average value was obtained $(\pi=45.9957)$ which means an increase of 1.1614 Whereas in the SSG group at the pretest, the average value was obtained $(\pi=44,9008)$ and at the posttest the average value was obtained $(\pi=45.2480)$ which means an increase of 0.3472 .

Table 3.

Results of Normality Test of Playing Skills Data

\begin{tabular}{llcccl}
\hline \multirow{2}{*}{ Digit Span Test } & \multirow{2}{*}{ Kelompok } & \multicolumn{3}{c}{ Shapiro-Wilk } & \\
& & Statistic & df & Sig. & Description \\
\hline \multirow{2}{*}{ Pre-Test } & SSG & 0.890 & 16 & 0.057 & Normal \\
& SSGT & 0.907 & 16 & 0.106 & Normal \\
Post-Test & SSG & 0.950 & 16 & 0.494 & Normal \\
& SSGT & 0.957 & 16 & 0.607 & Normal \\
\hline
\end{tabular}

Based on the results of the normality test in Table 3, it shows a significance value greater than $\alpha$ (sig. $>0.05$ ) in the SSGT group and the SSG group. So it can be concluded that the playing performance variable data in the two groups is normally distributed. Because it is in accordance with the decision making criteria if the value is sig. or probability value $\mathrm{P}>0.05$ (normal distribution).

Table 4.

Results of Normality Test of VO2 Max Data

\begin{tabular}{llcccl}
\hline \multirow{2}{*}{ Digit Span Test } & \multirow{2}{*}{ Kelompok } & \multicolumn{3}{c}{ Shapiro-Wilk } & \\
& & Statistic & df & Sig. & Description \\
\hline \multirow{2}{*}{ Pre-Test } & SSG & 0.890 & 16 & 0.057 & Normal \\
\multirow{2}{*}{ Post-Test } & SSGT & 0.907 & 16 & 0.106 & Normal \\
& SSG & 0.950 & 16 & 0.494 & Normal \\
& SSGT & 0.957 & 16 & 0.607 & Normal \\
\hline
\end{tabular}

Based on the results of the normality test in Table 4 , it shows a significance value greater than $\alpha$ (sig. $>0.05$ ) in the SSGT group and the SSG group. So it can be concluded that the VO2max variable data in the two groups is normally distributed. Because it is in accordance with the decision making criteria if the value is sig. or probability value $\mathrm{P}>$ 0.05 (normal distribution).

Table 5.

Homogeneity Test Results of Playing Skills Data

\begin{tabular}{lcccc}
\multicolumn{1}{c}{ Group } & Levena Statistic & df 2 & Sig. & Description \\
\hline SSG & 0.522 & 30 & 0.474 & Homogeneous \\
SSGT & 0.192 & 30 & 0.664 & Homogeneous \\
\hline
\end{tabular}


Based on the results of the homogeneity test in Table $\mathbf{5}$, it shows a significance value greater than $\alpha$ (sig.> 0.05) in the SSGT group and the SSG group. So it can be concluded that the performance variable data plays in the two groups of data variance is homogeneous.

Table 6.

Homogeneity Test Results of V02 Max Data

\begin{tabular}{lcccc}
\multicolumn{1}{c}{ Group } & Levena Statistic & df $\mathbf{2}$ & Sig. & Description \\
\hline SSG & 1.796 & 30 & 0.474 & Homogeneous \\
SSGT & 1,299 & 30 & 0.664 & Homogeneous \\
\hline
\end{tabular}

Based on the results of the homogeneity test in Table 6, the significance value is greater than $\alpha$ (sig.> 0.05) in the SSGT group and the SSG group. So it can be concluded that the VO2max variable data in the two groups of data variance is homogeneous After the data is assumed to have the distribution of normality and homogeneity of each group, the next step is hypothesis testing is carried out to prove the hypothesis that the author proposes based on the problem formulation.

Table 7.

T test results (paired sample $t$ test) playing skills

\begin{tabular}{lccc}
\multicolumn{1}{c}{ Group } & $\mathbf{t}$ & df $\mathbf{2}$ & Sig. \\
\hline SSG & 7.454 & 15 & 0.000 \\
SSGT & 3.907 & 15 & 0.001 \\
\hline
\end{tabular}

Based on Table 7, it shows that the significance value in the SSG group is smaller than $\alpha(0,000<0.05)$, which means that it shows that there is a significant increase in the effect of the small side games training program on improving playing performance in PORDA athletes in Kab. West Bandung. Likewise in the SSGT group, it means that it shows a significant increase from the small side games with tournament training program to improving playing performance in PORDA athletes in Kab. West Bandung.

Table 8.

$\mathrm{T}$ test results (paired sample $\mathrm{t}$ test) VO2 Max

\begin{tabular}{lccc}
\multicolumn{1}{c}{ Group } & $\mathbf{t}$ & df $\mathbf{2}$ & Sig. \\
\hline SSG & 1.456 & 15 & 0.116 \\
SSGT & 8.062 & 15 & 0.000 \\
\hline
\end{tabular}

Based on table 8, it shows that the significance value in the SSG group is greater than $\alpha(0.116>0.05)$, meaning that there is no significant increase in the small side games 
Influence of Small Side Games (SSG) on Aerobic Endurance and Handball Skills

Fitra Agung Aditya Pratama ${ }^{*}$, Yunyun Yudiana ${ }^{2}$, Tite Juliantine ${ }^{2}$

fitra.agung@upi.edu

training program on the increase in VO2max in PORDA athletes in Kab. West Bandung. Whereas in the SSGT group, this means that there is a significant increase in the small side games with tournament training program on the increase in VO2max in PORDA athletes in Kab. West Bandung.

Table 9.

Results of $t$ test (Independent Sample t test) Playing Skills

\begin{tabular}{lccccc}
\multicolumn{1}{c}{ Group } & \multicolumn{2}{c}{ Gain } & $\mathbf{t}_{\text {count }}$ & $\mathbf{t}_{\text {table }}$ & Description \\
\hline SSG & 2,43 & 1,30 & 0,58 & 2,04 & $\begin{array}{c}\text { Not } \\
\text { significant }\end{array}$ \\
SSGT & 2,90 & 2,97 & & & \\
\hline
\end{tabular}

Observing table 9, it is known that the difference in value from the small side games training program is an average of 2.431 with a standard deviation of 1.304 , while the average value of the small side games with tournament training program is 2.903 with a standard deviation of 2.972. After being processed using the $t$ test, it was found that $t$ count was $0.582>\mathrm{t}$ table 2.042 , meaning that there was no significant difference between the small side games training program and the small side games with tournament training program on the playing performance of the PORDA athletes in Kab. Bandung.

Table 10.

Results of $\mathrm{t}$ test (Independent Sample $\mathrm{t}$ test) VO2 Max

\begin{tabular}{lccccc}
\multicolumn{1}{c}{ Group } & \multicolumn{2}{c}{ Gain } & $\mathbf{t}_{\text {count }}$ & $\mathbf{t}_{\text {table }}$ & Description \\
\hline SSG & $\pi$ & $\sqrt{\boldsymbol{S}^{\mathbf{2}}}$ & & & Not \\
SSGT & 2,43 & 1,30 & 0,58 & 2,04 & significant \\
\hline
\end{tabular}

Based on Table 10, it is known that the difference in value from the small side games training program is obtained an average of 0.347 with a standard deviation of 0.953, while the value of the small side games with tournament training program is an average of 1.161 with a standard deviation of 0.576 , this means that the VO2max variable shows that the program small side games with tournament training has a better effect on increasing aerobic ability in PORDA athletes, Kab. West Bandung. And based on the t-test calculation results obtained tcount $2.923>2.042$ ttable, meaning that there is a significant difference between the small side games training program and the small side games with tournament training program on the increase in VO2max in PORDA athletes. West Bandung. 
Influence of Small Side Games (SSG) on Aerobic Endurance and Handball Skills

Fitra Agung Aditya Pratama ${ }^{1^{*}}$, Yunyun Yudiana ${ }^{2}$, Tite Juliantine ${ }^{2}$

fitra.agung@upi.edu

The results of the data findings in this study indicate that the group that used the small sided games training method had an increase in aerobic endurance or VO2max. This is evidenced by the results of data calculations, where the group using the small sided games training method had an increase in aerobic endurance but did not have a significant effect on increasing aerobic endurance or VO2max. Like Radziminski, Rompa, Barnat, Dargiewicz, \& Jastrzebski, (2013) small sided games are an efficient training method to develop aerobic capacity. Not only that, the data findings in this study also showed that the group using the small sided games training method had a significant increase in performance or playing skills. This is because the use of the small sided games training method focuses more on how athletes make decisions and act repeatedly in real situations. Therefore, the use of small sided games training methods is effective for developing the technical skills of the athletes themselves (Radziminski, Rompa, Barnat, Dargiewicz, \& Jastrzebski, 2013).

The results of the data findings in this study indicate that the Small sided games with tournament group exercise method has an increase in aerobic endurance or VO2max. This is evidenced by the results of data calculations, where the group using the small sided games with tournamnet training method has a significant effect on aerobic endurance abilities. Because small sided games are basically the training method chosen by coaches to utilize to increase aerobic capacity and technical performance, not only that SSG has been used to improve interaction between players and to develop technical and tactical abilities. This is due to the use of the small sided games with tournamet training method in a wider range of motion and the intensity of the movement is more active compared to the group using the small sided games method. There are several articles that say that the use of small sided games training methods is applied at least as effective in developing aerobic strength, speed, and endurance (Radziminski et al., 2013). The ability of aerobic endurance in the world of achievement, especially handball, is an important factor. Because with the better the ability of the athlete's aerobic endurance, the more repetition of technique movements will also have an impact on improving playing skills. The level of endurance determines the individual's ability to carry out fast and dynamic activities (Radziminski et al., 2013) Not only that, the findings in this study also showed that the group using the small sided games with tourament training method had a significant increase in performance or playing skills. This is because even though the actors both use the basic concept of small sided games, the material is different when giving the material. In this case, the group that uses the small sided games with 
Influence of Small Side Games (SSG) on Aerobic Endurance and Handball Skills

Fitra Agung Aditya Pratama ${ }^{1 *}$, Yunyun Yudiana ${ }^{2}$, Tite Juliantine ${ }^{2}$

fitra.agung@upi.edu

tournament training method is given a treatment with the method as if it were in a match situation, where the coaching team provides corrections when playing cannot immediately when an error occurs.

The findings of the data in this study indicate that the two groups that used the Small sided games with tournament training method and the small sided games training method had an increase from the initial pre-test to the post-test data. From the two research groups, the methods were almost the same but had different final results. In this study, the analysis used was the analysis of the average value of the increase in the two groups (gain score). There is no significant difference in the effect between the small sided games with tournament training method and the small sided games training method on the improvement of playing skills. This happens because the group that uses the small sided games training method with Small sided games with tournament in the process of implementing the athletes does a lot of repetition of the techniques in the training process, meaning that when the athlete uses the small sided games training method with Small sided games with technical or tactical tournament athletes trained greeting exercise program. It is different with the results of the VO2max group that used the small sided games with tournament training method, the effect or increase was significantly greater than the group using the small sided games training method in terms of aerobic endurance or VO2max. This is because the researcher uses small sided games with tournaent as a development method that combines the small sided games training method and the torunament game team (TGT). So that in using this method, the environmental space used during the treatment process is the same as the small sided games group, but what distinguishes it is because here it is based on tournaments or matches, the level of mobility or active movement of athletes is more than the group using small sided games. At the time of its implementation, the use of this method was not too much drilling and evaluation was carried out indirectly. Which means the evaluation is carried out when the match process with the agreed time has been completed. So based on these data, it can be concluded that in both groups there was an increase in aerobic endurance and playing skills, but in the small sided games group, aerobic endurance did not experience a significant increase. Although the two groups appear to have similarities with the application of the treatment for small sided games and small sided games with tournament training methods, there is a significant difference in the aspect of their aerobic endurance. 
Influence of Small Side Games (SSG) on Aerobic Endurance and Handball Skills

Fitra Agung Aditya Pratama ${ }^{1^{*}}$, Yunyun Yudiana ${ }^{2}$, Tite Juliantine ${ }^{2}$

fitra.agung@upi.edu

\section{CONCLUSIONS AND SUGGESTIONS}

Based on the results of the study, it can be concluded that there is no significant increase in the SSG training program to the increase in VO2max, while for the playing performance variable the SSG exercise program shows a significant increase. In the SSGT program, there is a significant increase in the increase in VO2max and playing performance in PORDA athletes in West Bandung Regency. Based on the results of the independent sample t-test, there is no significant difference between the SSG training program and the SSGT training program on playing performance, but there is a significant difference between the SSG training program and the SSGT training program on the increase in VO2max in PORDA athletes in West Bandung Regency.

\section{REFERENCES}

Aguiar, M., Botelho, G., Lago, C., Maças, V., \& Sampaio, J. (2012). A Review on the Effects of Soccer Small-Sided Games by, 33(June), 103-113. https://doi.org/10.2478/v10078-012-0049-x

Akbar, Y. (2013). Kemampuan Daya Tahan Anaerobik Dan Daya Tahan Aerobik Pemain Hoki Putra Universitas Negeri

Candra, O., Dupri, Gazali, N., Khairullazi, \& Oktari, A. (2019). Community Education Engagement Journal. In Community Education Engagement Journal (Vol. 1, Issue 1, pp. 58-66).

Corvino, M., Vuleta, D., \& Šibila, M. (2016). Analysis of Load and Players' Effort in 4vs4 Small-Sided Handball Games in Relation to Court Dimensions, 48, 213-222.

Costa, M. J., Balasekaran, G., Vilas-Boas, J. P., \& Barbosa, T. M. (2015). Physiological Adaptations to Training in Competitive Swimming: A Systematic Review. Journal of Human Kinetics, 49(1), 179-194. https://doi.org/10.1515/hukin-2015-0120

Davids, K., Arau $j$ o, D., Correia, V., \& Vilar, L. (2013). How small-sided and conditioned games enhance acquisition of movement and decision-making skills. Exercise and Sport Sciences Reviews, 41(3), 154-61. https://doi:10.1097/JES.0b013e 318292f3

Fraenkel, J. R., Wallen, N. E., \& Hyun, H. H. (2012). How to Design and Evaluate Research in Education. Climate Change 2013 - The Physical Science Basis (8 editions). New York: The McGraw-Hill Companies, Inc. https://doi.org/10.1017/CBO9781107415324.004

Griwijoyo, S. (2007). Ilmu Faal Olahraga: Funggsi Tubuh Manusia dalam Olahraga. Bandung: Jurusan Pendidikan dan Kepelatihan Olahraga. FPOK UPI.

Harsono. (2016). Kepelatihan Olahraga. Bandung : PT Remaja Rosdakarya offset. 
Kenney, W. L., Wilmore, J. H., \& Costill, D. L. (2012). Physiology of Sport and Exercise Fifth Edition. Human Kinetics(5th ed.). United States of America: Human Kinetics. https://doi.org/10.1007/978-

Manchado, C., García-Ruiz, J., Cortell-Tormo, J. M., \& Tortosa-Martínez, J. (2017). Effect of Core Training on Male Handball Players' Throwing Velocity. Journal of Human Kinetics, 56(1), 177-185. https://doi.org/10.1515/hukin-2017-0035

Martens, S. (2004). Succesfull coaching. United States: Human Kinetics

Milanese, C., Piscitelli, F., Lampis, C., \& Zancanaro, C. (n.d.). Anthropometry and body composition of female handball players according to competitive level or the playing position, (August 2013), 37-41. https://doi.org/10.1080/02640414.2011.591419

Radziminski, L., Rompa, P., Barnat, W., Dargiewicz, R., \& Jastrzebski, Z. (2013). A Comparison of the Physiological and Technical Effects of High-Intensity Running and Small-Sided Games in Young Soccer Players, 8(3), 455-466.

Tanzila, R. A., Chairani, L., \& Prawesti, S. A. (2018). Pengaruh Latihan Aerobik Terhadap Siswa SMP di Palembang. Palembang.

Taylor, P., Matthys, S. P. J., Vaeyens, R., Vandendriessche, J., Vandorpe, B., Coutts, A. J., Philippaerts, R. M. (2010). European Journal of Sport Science A multidisciplinary identification model for youth handball, 37-41. https://doi.org/10.1080/17461391.2010.523850

Warganegara, R. K. (2015). The Comparation of Lung Vital Capacity in Various Sport Athlete. Jurnal Majority, 4(2), 96-103. https://doi.org/10.1109/SP.1984.10002 